problems of technological education. He concluded by directing attention to the moral responsibility which, in his opinion, scientists and engineers should assume for the manner in which their work is used.

\section{The Australian Journal of Science}

Commencing with Vol. 20 (July 1957), the Australian Journal of Science, the organ of the Australian and New Zealand Association for the Advancement of Science, will be published nine, instead of six, times a year. The Journal is issued free to Fellows and annual members of the Association; for nonmembers the annual subscription, formerly $25 s$, is increased to $\mathrm{EA} 2$; but the cost per issue remains unchanged at 4s. $6 d$. Meetings of the Association are held every eighteen months and the report of each meeting is published in three special issues of the Journal so that two out of every three volumes of the Journal contain twelve numbers. The report of the proceedings of the thirty-second meeting of the Association, which was held at Dunedin during January 16-23, 1957, is published in the three special issues of Vol. 19. The first (19, No. $3 a$; January 1957) contains a list of the officers of the meeting; details of the general programme; the presidential address, "Biology and Medicine", delivered by Sir Macfarlane Burnet; the Liversidge Lecture, "Molecular Hydrodynamics : the Diffusion of Molecules and Ions through Liquids", by Prof. R. H. Stokes; and the addresses of the presidents of the Sections : A (Astronomy, Mathematics and Physics), B (Chemistry), C (Geology) and D (Zoology). The titles and authors of the other papers delivered in these four sections are also included, in addition to an appreciation of Prof. A. P. Elkin, the recipient of the Mueller Medal for 1957.

\section{Research for Industry}

THE London and Home Counties Regional Advisory Council for Higher Technological Education has issued a further survey of industrial research in progress in technical colleges in the region in 1956 under the title "Research for Industry" (Pp. 20. 1s. $6 d$.). The survey shows that since the previous report was issued in 1954, covering the period 194752 , there has been a marked development of collaboration between industry and the technical colleges. The report lists the investigations in progress, their sponsors and the technical college where they were undertaken. Besides work sponsored directly from industry, numerous investigations are being carried out for research associations, for Government depart. ments, particularly the Ministry of Supply, for the Atomic Energy Authority, and for the Central Electricity Authority, while others are financed by grants from the Department of Scientific and Industrial Research. At Chelsea Polytechnic, the Medical Research Council is supporting an investigation on the preparation of substituted triazaphenanthrenes of potential chemotherapeutic value, the British Empire Cancer Campaign is paying for electro-kinetic studies of bacterial surfaces, while at Acton Technical College studies in the flow between management and industry are being conducted for the Tavistock Institute of Human Relations.

\section{Economic Developments in the Middle East}

"Economic Developments in the Middle East, 1955-56" (London: H.M.S.O. 11s.), is part of the survey of the world economic situation prepared by the Secretariat of the United Nations, and issued as a supplement to World Economic Survey, 1956. Besides chapters on agriculture, industry, petroleum, foreign trade, and on monetary and fiscal charges and the price-level, it includes a preliminary review of the economic impact of the Suez Canal crisis on the Middle East. During the period, demand for Middle East exports maintained its upward trend, chiefly for petroleum, but also notably for cotton, the share of the U.S.S.R. and eastern Europe rising and that of Western Europe declining. There were comparable increases and shifts in imports and their sources of supply. There was little change in the inflow of capital, and among development projects the major emphasis was on agriculture, irrigation and transport. Two major dams were completed in Iraq and two others in Turkey, and also the railroad from Tehran to Meshed in north-east Iran. The annual rate of increase in production of crude petroleum rose from 12.8 per cent in 1954 to 18.3 per cent in 1955 but decreased in 1956, mainly owing to the sharp decline in the last two months of the year. Expansion of refining capacity in 1955 raised the crude annual charging capacity of the region to more than 66 million tons, and in the sutumn of 1956 the twenty refineries and topping plants were operating at 50 million tons per annum, an increase of about 35 per cent over the average for 1955, when the region processed 23 per cent of its production or $5 \cdot 6$ per cent of the world's refined products ; the figure for 1956 is probably higher. Industrial output inereased sharply in 1955, but the overall increase in 1956 was probably less.

\section{The Pacific Science Board}

The tenth annual report of the Pacific Science Board (pp. 50. Washington, D.C. : National Academy of Sciences) records that the principal scientific activity in Micronesia has been the coral atoll programme, involving an ecological approach to the study of environmental factors affecting life on coral atolls. H. J. Wiens continued his interpretive study of man and Nature in the atoll environment, and besides visiting thirteen atolls in the Marshall Islands to study the individual features of different coral atolls, he was able to obtain comparative information on the human ecology of the Marshallese to relate to his findings in the Caroline Islands. F. R. Fosberg obtained comparative information in a visit to the Maldive Islands. Three numbers of the Atoll Research Bulletin were issued and twelve volumes on insects of Micronesia. Field-work continued in the threeyear study of the biology and ecology of Pacific island rats at Ponape, Eastern Carolines, where valuable information is being acquired on the natural history and ecology of rats, and the field team co-operated with the Trust Territory's biennial training programme for sanitary officers by conducting a programme on rodent control. A study of sea turtles by J. R. Hendrickson has special reference to measures to assure the conservation of the turtle, and support was again given to the marine biological programme of the George Vanderbilt Foundation at Stanford University, which included investigations on the relations of fishes to their environment, the study of the estuarine-mangroves and fresh-water fishes of the Palau Islands, an entomological survey of scale insects and a study of sea currents about tho Palau Islands. 